\title{
Narracja autobiograficzna i języki dobra ${ }^{1}$
}

\section{Life Narrative and Languages of the Good}

Dobro jest suwerenne, twierdzi Iris Murdoch - w tym sensie, że podejmowanie decyzji etycznych wynika ze „struktur wartości” tworzonych wokół nas w ciągłym procesie uwagi moralnej skupionej na realiach codziennego życia. Ale w jakim stopniu można takie ujęcie dobra traktować poważnie? Starożytni filozofowie, zwłaszcza Platon, uznawali struktury wartości za rzeczywistość metafizyczną nieodłączną od wszechświata ${ }^{2}$, nowożytny sceptycyzm jednak solidnie nadwyrężył to stanowisko. W 301. ustępie Wiedzy radosnej Friedricha Nietzsche rozprawia się z tym właśnie odwiecznym i aż nazbyt ludzkim poglą$\mathrm{dem}^{3}$, że nasze wartości należą do stanu rzeczy:

Co tylko w dzisiejszym czasie ma wartość, to nie posiada jej w sobie, wedle natury swej - natura jest zawsze bez wartości -: jeno nadano, darowano temu kiedyś wartość, a my byliśmy tymi dawcami i darowującymi! My dopiero stworzyliśmy świat, który obchodzi coś człowieka! - Lecz właśnie brak nam wiedzy o tem i jeśli ją kiedyś jakiejś chwili uchwycimy, to zapominamy znów o niej w najbliższej $(\ldots)^{4}$.

Od czasów Nietzschego nauki przyrodnicze oddziałują na nas tak silnie, że opinia ta utraciła swoją niegdysiejszą ostrość. Oswoiliśmy się z myślą, że

1 Tekst jest obszernym fragmentem pierwszego rozdziału książki Davida Parkera The Selfin Moral Space: Life Narrative and the Good, Ithaca: Cornell University Press 2007. Rozdział składa się z czterech podrozdziałów. Pominięto tylko ostatni z nich, dotyczący Ecce Homo Nietzschego.

2 Jest to fundamentalna myśl Platona, która przewija się przez jego twórczość i wiąże się ściśle z teorią Form. Wiedza o rzeczywistości, w przeciwieństwie do zwykłego mniemania, jest wiedzą o Formach. W podobny sposób wiedza o prawdziwym dobru, w przeciwieństwie na przykład do reputacji i bogactwa, które nie są dobrami moralnymi, jest wiedzą o Formie lub zasadniczej naturze Dobra (zob. Państwo VI 508).

3 Oczywiście, Nietzsche uderza tu przede wszystkim w chrześcijaństwo, a nie w platonizm.

4 F. Nietzsche, Wiedza radosna, tłum. L. Staff, Warszawa 1906-1907, s. 246. 
wartości nie tkwią we wszechświecie per se, lecz są mu przez nas narzucane ${ }^{5}$. Być może mniej swojska jest myśl, że nie umiemy żyć z tak przygnębiającą wiedzą i dlatego natychmiast staramy się ją stłumić. Wcześniej Nietzsche twierdzi, że złudzenia takie jak te dotyczące wartości są oszukiwaniem siebie, filozoficznym „błędem”, przetrwały zaś na skutek doboru naturalnego, bo - jak się okazało - sprzyjają „zachowaniu życia”. Walkę między takimi „błędami” a surową „prawdą” Nietzsche postrzega jako główny konflikt nadchodzącej epoki:

W porównaniu z ważnością tej walki reszta jest obojętna: postawiono tu ostatecznie pytanie co do warunku życia i tu po raz pierwszy usiłuje się doświadczeniem na pytanie to odpowiedzieć. Jak dalece prawda daje się wcielać? - oto pytanie, na tem polega doświadczenie ${ }^{6}$.

\section{Uchwycić jak najlepiej sens życia}

Omawiając znaczenie twórczości Charlesa Taylora dla narracji autobiograficznej, chciałbym zacząć właśnie od pytania Nietzschego. W jakiej mierze to, co Nietzsche nazywa prawdą o wartościach, da się wcielać w codzienne życie? W mojej argumentacji istotna jest też opinia, że pytanie to łączy się z „doświadczeniem” (u Taylora $\mathrm{z}$ „testem” powszedniej stosowalności różnych teorii bytu). Nietzsche nawiązuje tu do czegoś, co Bernard Williams nazywa bezwzględną koncepcją wszechświata ${ }^{7}$, pozbawioną wszelkich pojęć „,antropocentrycznych”, takich jak wartości, które według Nietzschego sami rzutujemy na świat natury. Ujmując to we współczesnych kategoriach: Nietzsche rozważa, w jakiej mierze można kierować się w życiu taką „koncepcją bezwzględną” oraz wyprowadzonymi z niej objaśnieniami i metafizyką, a zatem rozumieć świat człowieka, myśleć o nim i żywić wobec niego odczucia, mając trzeźwe przekonanie, że wartości są po prostu naszą projekcją.

Nie jest bynajmniej oczywiste, czy sam Nietzsche sądził, że taki sposób życia jest możliwy. W Wiedzy radosnej śledzimy jego tok myślenia i odczucia wobec

5 Myśl tę można dostrzec niemal wszędzie, ale z perspektywy literaturoznawczej ciekawy wydaje się artykuł Johna Careya pod znamiennym tytułem An End of Evaluation [Koniec osądu], „Times Literary Supplement”, 22 February 1980, 4013. Carey nie wątpi, że wartości to ludzka projekcja: „Współczesny człowiek przywykł do poglądu, że (...) dobro, zło i tym podobne efemerydy zostały stworzone przez ludzki umysł, który usiłuje nadać jakieś znaczenie amoralnemu nurtowi stanowiącemu rzeczywistość", s. 204.

${ }^{6}$ F. Nietzsche, Wiedza radosna, dz. cyt., s. 153-156.

7 B. Williams, Ethics and the Limits of Philosophy, Cambridge (Mass.) 1985, s. 139 i n.

${ }^{8}$ Ch. Taylor, Źródta podmiotowości. Narodziny tożsamości nowoczesnej, Warszawa 2001, s. 117. 
świata, „który obchodzi coś człowieka”. Nieco dalej, w ustępie 304, niemiecki filozof zwraca się od metafizyki ku etyce:

Pozbywamy się, czyniąc. - W gruncie rzeczy wstrętne mi są wszystkie owe moralności, które mówią: „Nie czyń tego! Wyrzeknij się! Przezwycięż się” - sprzyjam natomiast wszystkim owym moralnościom, które mnie pobudzają, by coś czynić i powtarzać i od rana do wieczoru i w nocy śnić o tem i o niczem nie myśleć jak: by to dobrze zrobić, tak dobrze, jak ja to tylko mogę! Kto tak żyje, od tego odpada ustawicznie jedno po drugiem to, co do takiego życia nie należy: bez nienawiści i odrazy widzi on, że dziś to, jutro owo rozbrat z nim weźmie, podobnie liściom pożółkłym, które każdy żywszy powiew drzewu porywa: lub nie widzi wcale, że coś z nim rozbrat bierze, tak surowo patrzy oko jego w swój cel i wogóle [sic!] poprzód siebie, nigdy w bok, wstecz, w dół. „Działanie nasze ma określać, czego czynić nie mamy: nie czynimy czyniąc" - tak podobam sobie, tak brzmi moje placitum. Lecz nie chcę z otwartemi oczyma dążyć ku swemu zubożeniu, nie znoszę żadnych cnót zaprzecznych - cnót, których istotą jest zaprzeczanie i odmawianie sobie?

Oto Nietzsche jako bezlitosny krytyk etyki judeochrześcijańskiej, który w książce $Z$ genealogii moralności obszernie omówi swoją niechęć do służalczego wyrzekania się siebie. W cytowanych słowach można zresztą dopatrzyć się zalążka wszystkich jego późniejszych tekstów, w tym krytyki chrześcijańskiego resentymentu (zob. 305), przeciwstawionego zdrowej ascezie samodoskonalenia. Wytrwała praca, która „bez nienawiści i odrazy” uwalnia nas od rzeczy zbędnych, jest konieczna do samorealizacji, by robić coś tak ,jak ja to tylko mogę”. Wcześniej, w epigramatycznym wpisie Co mówi ci sumienie? (270), Nietzsche powtarza za Pindarem: „winieneś stać się tym, kim jestes”" ${ }^{10}$. Tu znowu spoglądamy w przyszłość: podtytuł autobiografii Nietzschego Ecce Homo brzmi: „Jak się staje, czym się jest”. W jednym z dalszych rozdziałów będę starał się wykazać, że atakując chrześcijaństwo, Nietzsche nie zamierzał wspierać nihilizmu ${ }^{11}$. Jego rewolucyjny program zakładał „przewartościowanie wszystkich wartości”, a nie ich dewaluację. Według niemieckiego filozofa stawanie się tym, kim się jest, poprzez zdrową ascezę robienia tego, czego nikt inny tak zrobić nie może, jest znacząco lepszym sposobem bycia niż stosowanie się do moralności niewolników, która uczy nienawiści do samego siebie.

Wracając do Nietzscheańskiego pytania o to, ,jak dalece prawda daje się wcielać": u samego filozofa obserwujemy w praktyce jeden rodzaj moralności wykorzeniany na korzyść drugiego. Opinia, że wartości są naszą subiektywną projekcją, jest oczywiście ogromnie pomocna w przygotowaniu gruntu pod ten

9 F. Nietzsche, Wiedza radosna, dz. cyt., s. 249.

10 Tamże, s. 219.

${ }^{11}$ Chodzi o podrozdział Nietzsche's "Ecce Homo”: Inescapable Frameworks of the Good (s. 38-55), który zamyka prezentowany tu pierwszy rozdział książki Parkera (przyp. redakcji). 
proces, ale czy faktycznie mamy tutaj do czynienia z autentycznym wcielaniem? Wcielanie radykalne - można by mniemać - łączy się z poglądem, że stawanie się tym, kim się jest, zasadniczo nie jest w niczym lepsze od przepojonego resentymentem wyrzeczenia się siebie, tylko tak po prostu zdecydował Nietzsche. Dlaczego jednak filozof miałby w tej sytuacji uważać jedną moralność za „wstrętną”, a „sprzyjać” drugiej? Innymi słowy, za wyrażonymi w 304 odczuciami i intuicjami bezsprzecznie stoją jakieś przyczyny (choćby te wyłożone dokładniej w późniejszych pracach Nietzschego) ${ }^{12}$. Własne postępowanie dowodziłoby zatem, że sam filozof nie odczuwa, nie myśli ani nie dokonuje wyborów zgodnie z „koncepcją bezwzględną” przedstawioną w 301.

Jest to jednak argument ad hominem, który oznacza tylko, że Nietzsche jak można sądzić - nie wciela propagowanego przez siebie metafizycznego sceptycyzmu we własne myślenie, oceny i odczucia dotyczące ludzkiego świata. Argument ten nie oznacza natomiast, że Nietzsche nie byłby w stanie tego zrobić. Taylor, idąc dalej, pragnie wykazać, że taki sposób życia jest po prostu niemożliwy. W Źródtach podmiotowości opowiada się przeciwko wszelkim formom antyrealizmu wartości, w tym przeciwko poglądowi Nietzschego:

Nasze pojęcia wartościujące dają nam wgląd w naturę ludzkiego życia we wszechświecie, ta zaś sprawa nie ma wiele wspólnego z tym, co starają się ujawnić i wyjaśnić nauki przyrodnicze. Ta rzeczywistość oczywiście zależy od nas, w tym sensie, że warunkiem jej istnienia jest istnienie nas samych. Skoro już jednak istniejemy, nie jest ona wcale subiektywną projekcją, podobnie jak nie jest nią przedmiot fizyki ${ }^{13}$.

Chodzi tu o realizm wartości, zgodnie z którym odczucia moralne w rodzaju Nietzscheańskich są reakcją na coś rzeczywistego, co odsłania się przed filozofem w świetle takich pojęć wartościujących jak „zubożenie”, „ten, kim jestes”” i „dobrze to zrobić”. Pojęcia te wiążą się z czymś, co Taylor nazywa dobrami silnie wartościowanymi. Uzasadnienie realizmu wartości brzmi następująco:

1. Nie możesz nie odwoływać się do silnie wartościowanych dóbr w następujących sytuacjach życiowych: podejmowanie decyzji, osąd sytuacji, zastanawianie się nad własnymi odczuciami wobec ludzi itp. Owo „nie możesz” (...) [o]znacza (...), że potrzebujesz tych pojęć, aby najlepiej oddać sens tego, co robisz. Na tej samej zasadzie pojęcia te są niezbędne do tego rodzaju wyjaśniania i rozumienia samego siebie i innych, który powiązany jest z tymi życiowymi sposobami ich stosowania: do

12 Zdaniem Taylora (Human Agency and Language, Cambridge 1985, s. 29) oceny oparte na przyczynach ipso facto nie płyną jedynie z radykalnego wyboru. Nietzsche pokazuje w praktyce, że jego ocena - na przykład - chrześcijańskiego resentymentu ma swoją przyczynę: resentyment jest autodestrukcyjny. Postawa ta nie jest więc dla niego czymś złym po prostu dlatego, że postanowił ją za taką uznać. W Human Agency and Language Taylor zarzuca Sartre'owi pokrewną niekonsekwencję.

${ }^{13}$ Ch. Taylor, Źródta podmiotowości. Narodziny tożsamości nowoczesnej, dz. cyt., s. 117. 
oceny czyjegoś postępowania czy pojęcia czyichś motywów albo do zrozumienia, o co ci właściwie chodziło przez te wszystkie lata itd.

2. Rzeczywiste jest to, z czym musisz sobie radzić, co nie zniknie tylko dlatego, że nie zgadza się z twoimi przesądami. Dlatego też to, do czego nie możesz się nie odwoływać w swym życiu, jest rzeczywiste, albo też tak bliskie rzeczywistości, jak to tylko dla ciebie możliwe w tym momencie. Twój ogólny metafizyczny obraz „wartości” i ich miejsca w „rzeczywistości” powinien opierać się na tym, co jawi ci się w ten sposób jako rzeczywiste. (...)

Nawet nierealiści niejasno odczuwają moc tej argumentacji. Dociera ona do nich w postaci nieokreślonego poczucia, że przyjęcie tezy o projekcji powinno mieć destrukcyjne skutki dla moralności pierwszego rzędu. To samo poczucie - poczucie, że tego, z czym liczą się w swoim życiu: dóbr i narzucanych przez nie wymagań, zupełnie nie da się uzgodnić z tezą o projekcji - pojawia się u wszystkich ludzi, zanim zawładnie nimi filozoficzna racjonalizacja. Aby być w zgodzie z tym poczuciem, zwolennik tej tezy musiałby całkowicie odrzucić moralność, taką jak się ją zwykle rozumie, tzn. jako domenę silnych wartościowań. Jednakże większość nierealistów niechętnie idzie tą drogą. Sami wyznają jakąś moralność i nawet oni niejasno pojmują myśl wyrażoną w uwadze 1 , że nie dałoby się działać w ten sposób. (...)

Jeśli nierealizm nie może być wsparty przez doświadczenie moralne, to nie ma żadnych powodów, by weń wierzyć ${ }^{14}$.

Zanim przejdziemy do wniosków z argumentacji Taylora, warto przyjrzeć się niektórym użytym tu pojęciom.

„Dobra silnie wartościowane” i „silne wartościowania” to kluczowe terminy Taylorowskie. Wartościowanie może być „słabe”, kiedy po prostu czegoś pragnę, coś wybieram lub wolę coś od czegoś innego - na przykład mercedesa od bmw - i może być „silne”, na przykład kiedy w ogóle rezygnuję z kupna samochodu, ponieważ korzystanie z własnego auta przyczynia się do globalnego ocieplenia. W tej drugiej sytuacji dochodzi do rozróżnienia między wyborem wyższym i niższym, lepszym i gorszym, słusznym i niesłusznym rozróżnienia, którego nie uzasadnia sam wybór, ale które dostarcza kryteriów, by ten wybór ocenić ${ }^{15}$. Silne wartościowanie polega na tym, że pewne pragnienia, wybory lub preferencje mogą być oceniane jako niegodziwe, haniebne, powierzchowne, destruktywne, niemądre i tak dalej ${ }^{16}$. Posługując się podanym tu przykładem, powiedzielibyśmy, że słabo wartościowanym dobrem byłby większy komfort jazdy mercedesem, a troska o środowisko nakłaniająca

\footnotetext{
14 Tamże, s. 118-120.

15 Tamże, s. 12 i n.

16 Taylor omawia tę kwestię szerzej w Human Agency and Language, dz. cyt., s. 18 i n.
} 
mnie do korzystania z transportu publicznego łączy się z dobrem silnie wartościowanym. Powracając zaś do Nietzscheańskiej moralności z ustępu 304, należy zauważyć, że omawiając wybór samorealizacji zamiast wyrzeczenia się siebie, filozof niekiedy używa języka słabego wartościowania: „tak podobam sobie”, „sprzyjam”, w słowach „wstrętne mi są” natomiast pobrzmiewa już pogarda, jaką Nietzsche wyrazi w późniejszych tekstach wobec judeochrześcijańskiej moralności niewolników. Stawanie się tym, kim się jest, to dobro silnie wartościowane - element czegoś, co Nietzsche określi jako amor fati: element mężnej afirmacji własnego losu, życia „bez nienawiści i odrazy”. Wszystko to jest dla niemieckiego filozofa zdecydowanie kwestią „sumienia”.

Taylor stara się pokazać, że nie można żyć bez uciekania się do takich silnie wartościowanych dóbr. Argumentuje, że jeżeli jest się stosunkowo normalną osobą, to zna się swoje stanowisko wobec wielu nieuniknionych pytań o to, co jest dobre, a co złe, co godne podziwu, a co pogardy, co warto robić, czego nie warto, co ma znaczenie, co zaś jest banalne i drugorzędne. Odpowiedzi na te pytania definiują, kim jesteśmy, i nieuchronnie dotyczą dóbr silnie wartościowanych - tego, co postrzegamy jako ważne czy znaczące w swoim życiu. Według Taylora tożsamość człowieka wiąże się z ukierunkowaniem na silnie wartościowane dobra. Wiedzieć, kim się jest, to być zorientowanym $\mathrm{w}$ tak zwanej przestrzeni moralnej: w przestrzeni zarysowanych powyżej pytań o własne poglądy, o to, jakie istotne dobra lub wartości wytyczają dla nas horyzont znaczenia ${ }^{17}$.

Taylor liczy na to, że dotrzemy do sedna tego fenomenologicznego ujęcia tożsamości. Na przykład typowe ujęcia, łącząc samookreślanie się z przynależnością do grupy, często pomijają to, że nie każda grupa, do której należymy, jest dla nas znacząca czy ważna, a wiele wartości definiujących naszą tożsamość - choćby podziw, jaki odczuwamy dla odwagi cywilnej - może z przynależnością do grupy nie mieć bezpośrednio nic wspólnego. Taylor proponuje też eksperyment myślowy: spróbujmy wyobrazić sobie kogoś nieukierunkowanego na żadne silnie wartościowane dobra. Byłby to człowiek niezdolny do rozstrzygnięcia, co warto zrobić, a czego nie warto, co jest dobre, a co złe, co istotne lub drugorzędne. Chodzi nie tylko o to, że ktoś taki byłby powierzchowny czy niefrasobliwy w kwestiach moralnych, lecz o to, że byłby pogrążony w potężnym „kryzysie tożsamości” i miałby głęboko, wręcz patologicznie zdezorientowaną psychikę, pozostając poza tym, co uznalibyśmy za normę. Stosunkowo normalny człowiek musi orientować się jakoś w przestrzeni moralnej: „horyzonty, wewnątrz których żyjemy, muszą obejmować mocne rozróżnienia jakościowe"18. Bez takich horyzontów trudno w ogóle rozpoznać w kimś „osobę” czy „podmiot”.

\footnotetext{
${ }^{17}$ Ch. Taylor, Źródta podmiotowości. Narodziny tożsamości nowoczesnej, dz. cyt., s. 52 i n.

${ }_{18}$ Tamże, s. 62.
} 
Nasuwa się wniosek, że osoby mają swoje „konstytutywne” zainteresowania: „jesteśmy podmiotami jedynie dzięki temu, że pewne sprawy coś dla nas znaczą. To, czym jestem jako podmiot, moja tożsamość, jest określane zasadniczo przez sposób, w jaki rzeczy mają dla mnie znaczenie" ${ }^{19}$. Zainteresowania te - horyzonty orientacyjne, ramy pojęciowe - które konstytuują nas jako podmioty, nie są bynajmniej czymś wrodzonym. Wprowadzają nas w nie nasi rozmówcy ${ }^{20}$. Jak stwierdza Taylor (przywodząc na myśl poglądy Michaiła Bachtina), podmiotem możemy być tylko w obrębie „sieci rozmowy” ${ }^{21}$. Począwszy od starań naszych pierwszych opiekunów przez całe życie zapoznajemy się z językami „moralnej i duchowej orientacji”, które są zarazem językami „rozumienia siebie” lub „samookreślenia”22. Języki te obejmują takie słowa wartościujące, jak „miłość”, „uczciwość”, „odwaga”, „okrucieństwo”, w których - argumentuje Bernard Williams - wymiary opisu i oceny są nierozdzielne ${ }^{23}$. Takimi właśnie słowami trzeba umieć się posługiwać, by „rozeznawać” kluczowe cechy w sobie i innych, oceniać sytuacje i ludzi, wyrażać uczucia, osądzać postępowanie, rozumieć motywy itd. Odwołując się do Gilberta Ryle’a i Clifforda Geertza ${ }^{24}$, Williams określa te terminy jako „gęste pojęcia etyczne” 25 - pojęcia należące do kodów znaczeniowych, które funkcjonują w danej kulturze lub „sieci rozmowy”. Języki dobra konstytuowane przez te pojęcia różnią się zatem w poszczególnych kulturach i okresach, a kultura o dużej złożoności, taka jak ta panująca współcześnie na Zachodzie, składa się z wielu takich języków.

Wróćmy do naszego pytania o to, czy można żyć, kierując się jakąś „koncepcją bezwzględną" rzeczywistości. Taylor stara się dowieść, że aby uchwycić sens naszego życia, potrzebujemy "gęstych” antropocentrycznych języków wartościowania, ponieważ „rzadkie” teoretyczne języki wyjaśnień opartych na „koncepcji bezwzględnej” same nie są w stanie dać nam takiego rozumienia.

Na czym polegają warunki tego, by można było mówić, że coś „oddaje sens” naszego życia? Te warunki nie są jeszcze spełnione, gdy mamy jakiś teoretyczny język, który rości sobie pretensje do wyjaśnienia ludzkiego zachowania z punktu widzenia obserwatora, jest jednak bezużyteczny dla samego działającego, gdy stara się on oddać sens swego własnego myślenia, odczuwania i działania. Zwolennicy jakiejś teorii redukcjonistycznej mogą pogratulować sobie wyjaśnień, które potrafią obejść się bez któregoś z terminów stosowanych w życiu codziennym - takich jak na przykład „wolność”, „godność” - czy wspomnianych wyżej terminów odnoszących się

19 Tamże, s. 65-66.

${ }^{20}$ Tamże, s. 69.

${ }^{21}$ Tamże, s. 70.

22 Tamże, s. 69-70.

${ }^{23}$ B. Williams, Ethics and the Limits of Philosophy, dz. cyt., s. $140 \mathrm{i} \mathrm{n.}$

${ }^{24}$ G. Ryle, Czym jest umyst?, tłum. W. Marciszewski, Warszawa 1970; C. Geertz, Interpretacja kultur. Wybrane eseje, tłum. M. Piechaczek, Kraków 2005.

${ }^{25}$ B. Williams, Ethics and the Limits of Philosophy, dz. cyt., s. 140. 
do cnót, które nie dają się rozbić na „odniesione do faktów” i „oceniające” składniki znaczenia. Lecz nawet gdyby ich wyjaśnienia w trzeciej osobie były bardziej prawdopodobne, niż są w rzeczywistości, jakie by to miało znaczenie, skoro owe terminy nie dałyby się wykorzenić z niewyjaśniających wypowiedzi w pierwszej osobie? Przypuśćmy, że przekonam samego siebie, iż mogę wyjaśnić zachowanie ludzi jako obserwator bez użycia terminu „godność”. I czegóż to dowodzi, skoro nie potrafię obejść się bez tego terminu w moich własnych rozważaniach nad tym, co robić, jak się zachować, jak traktować ludzi; w moich własnych pytaniach o to, kogo podziwiam, do kogo czuję sympatię itp.?26

Gęste języki antropocentryczne nie pozwalają się wykorzenić, bo każdemu z nas jako działającemu w ludzkim świecie są potrzebne do rozmaitych nieuniknionych zastosowań w pierwszej osobie. $Z$ tego powodu są nieodzowne do uchwycenia sensu naszego życia, kiedy oceniamy, myślimy, czujemy i - jak będę argumentował - kiedy zamierzamy o tym pisać.

Taylor jednak chce pójść jeszcze dalej: języki duchowego i moralnego rozeznawania są nam potrzebne, by uchwycić sens naszego życia jak najlepiej. Autor Źródet podmiotowości odnosi się tu bezpośrednio do „rzadkich” języków teoretycznych, które rzekomo „interpretują" i „wyjaśniają” nasze życie z jakiegoś trzecioosobowego punktu widzenia, rozmijając się na ogół ze znaczeniem dostrzeganym przez nas. W tym kontekście pada pytanie: „Cóż jednak mogłoby przezwyciężyć język, w którym w rzeczywistości przeżywam moje życie?”27. Odpowiadając, Taylor formułuje zasadę najlepszego objaśnienia (NO):

Pojęcia, które dobieramy, muszą mieć sens w całym zespole różnych sposobów użycia, zarówno wyjaśniających, jak i życiowych. Pojęcia niezbędne dla tego drugiego są częścią opowieści, która najlepiej nas charakteryzuje, chyba że (i do czasu gdy) będziemy je mogli zastąpić pojęciami bardziej przenikliwymi. Wynik owego dążenia do większej przenikliwości przedstawia najlepsze z możliwych w danym czasie objaśnień, i żadne bardziej ogólne epistemologiczne czy metafizyczne rozważania na temat nauki czy przyrody nie mogą uzasadnić zignorowania tego objaśnienia. Najlepsze objaśnienie w powyższym sensie odznacza się największą siłą. Pozwolę sobie nazwać to stwierdzenie zasadą $\mathrm{NO}^{28}$.

Jednym ze sprawdzianów „zasady NO” jest to, czy dany język pozwala nam rozumieć, wyjaśniać lub wyrażać nasze odczucia i intuicje moralne dotyczące nas samych i innych ludzi, dobrego i słusznego postępowania i tak dalej. Jeśli tak nie jest, język ten nie spełnia zasady NO. Rzadkie języki teoretyczne wywiedzione z epistemologii czy metafizyki, które wymagają od nas lekceważenia

\footnotetext{
${ }^{26}$ Ch. Taylor, Źródta podmiotowości. Narodziny tożsamości nowoczesnej, dz. cyt., s. 113-114.

${ }^{27}$ Tamże, s. 115.

${ }^{28}$ Tamże, s. 116.
} 
znaczeń, jakie rozpoznajemy intuicyjnie w ludzkiej rzeczywistości, są propozycjami „zmiany przedmiotu” ${ }^{29}$.

Zmiana przedmiotu to użyteczne pojęcie zapożyczone przez Taylora od Donalda Davidsona ${ }^{30}$. Taylor się nim posługuje, by wskazać na naturalistyczną redukcję etyczną, zgodnie z którą wszelkie filozofowanie moralne powinno się zaczynać poza powszednimi znaczeniami, w jakiejś naukowej koncepcji bezwzględnej wszechświata. Pojęcie to jest jednak równie pomocne przy rozpatrywaniu redukcjonistycznych ujęć ludzkiej rzeczywistości, które nadal cieszą się dużą popularnością w literaturoznawstwie. Przydaje się też, jak zobaczymy, kiedy się postuluje, by ujęcie analityczne wyprowadzać z systemów języka, a wszystkie moralne intuicje, uczucia i sensy antropocentryczne postrzegać jako zapośredniczone przez zróżnicowaną grę znaków językowych o stale odraczanym znaczeniu. Wymóg, by najpierw badać systemy dyskursu, praktyki oznaczania czy zróżnicowany układ sił w społeczeństwie, może właśnie być propozycją zmiany przedmiotu - przy czym preferowanym przedmiotem jest tutaj „teoria”.

Kwestia, czy postsaussure'owskie lub postnietzscheańskie teorie są w stanie sprostać zasadzie $\mathrm{NO}$ w odniesieniu do narracji autobiograficznej, wiąże się ściśle z naszym począ tkowym pytaniem, czy nietzscheański antyrealizm wartości da się wcielać w codzienne życie. Jak wiemy, „przedmiot” łatwo można skonceptualizować w rzadkiej przestrzeni teoretycznej. Literaturoznawcy robią to bez przerwy. Trzeba w tym celu oderwać się myślowo od konstytutywnego dla nas pierwszoosobowego zainteresowania tym, co dla nas ważne i znaczące, i zobrazować nas sobie z trzecioosobowej perspektywy jako część większego systemu, która jest w pewnej mierze przez ów system determinowana - powiedzmy, przez system znaków językowych, praktyk dyskursu czy układu sił. W zasadzie NO kluczowe jest to, „do jakiego stopnia można naprawdę zająć takie stanowisko i żyć zgodnie z nim”. Sam Taylor zaś wątpi, czy „współczesne neonietzscheańskie teorie przezwyciężenia podmiotowości lub "podmiotu" mogą przejść ten test" ${ }^{31}$.

Dalsze rozważania są po części próbą naświetlenia tej właśnie kwestii. Przyjrzymy się dwóm pokrewnym pytaniom: czy można zrozumiale pisać o swoim życiu i czy można zadowalająco zrozumieć takie pisarstwo bez uciekania się do gęstych antropocentrycznych języków moralnego i duchowego rozeznawania? Skoncentruję się na autobiografiach, które rzekomo są sprzeczne lub pod jakimś względem nie do pogodzenia z uzasadnianym tu poglądem. Zacznę od „antyautobiografii” Roland Barthes, którą traktuję jako graniczny przypadek możliwości - lub niemożliwości - pisania o własnym życiu w rzadkich

${ }^{29}$ Tamże, s. 115-116.

${ }^{30}$ D. Davidson, Zdarzenia mentalne, tłum. T. Baszniak, D. Davidson, Eseje o prawdzie, jezyku i umyśle, Warszawa 1992, s. 179.

${ }^{31}$ Ch. Taylor, Źródta podmiotowości. Narodziny tożsamości nowoczesnej, dz. cyt., przyp. 20, s. 81 . 
językach teorii postsaussure'owskiej. Zanim to jednak zrobię, chcę dla zilustrowania moich argumentów omówić życiorys, który przedstawia główne Taylorowskie idee w praktyce. A ponieważ stanowisko Taylora - tak jak je dotąd prezentowałem - dotyczy koniecznych ram pojęciowych, transcendentalnych warunków bycia podmiotem i przeżywania życia, przez co nie jest specyficzne dla kultury Zachodu, strategicznie zajmę się najpierw przykładem zaczerpniętym z cywilizacji niezachodniej.

\section{Autorelacja Wang Shimina: życie przykładne}

Autorelacja Wang Shimina (1592-1680) to ośmiostronicowy dodatek do przełomowego dzieła Wu Pei-yi The Confucian Progress: Autobiographical Writings in Traditional China. Wang pochodził ze znamienitej i bogatej rodziny. Jego dziadek Wang Hsichue pełnił urząd wielkiego sekretarza (1585-1594) w administracji państwowej pod koniec dynastii Ming, ciesząc się opinią prawego uczonego i literata. Sam Wang Shimin był cenionym malarzem, jednym z „Czterech Wangów” tworzących w XVII wieku'.

Jak czytamy, Wang Shimin napisał Autorelację, by przechowywano ją w świątyni przodków dla:

potomków w następnych pokoleniach. (...) Dzięki temu dokumentowi prześledzą wszystko aż do napomnień mojego ojca i dziadka. Niech starają się naśladować dawne obyczaje i dbają, by w niczym nie umniejszyć reputacji rodziny. Może kiedyś zdołają przywrócić chwałę rodu przez to, że kilku jego członków będzie w jednym czasie służyć władzom na wysokich urzędach ${ }^{33}$.

Życzenie Wang Shimina przynajmniej w części się spełniło: jego wnuk uzyskał w administracji dynastii Qing równie znaczącą pozycję co prapradziadek za dynastii Ming. Sam Wang Shimin, lojalny stronnik Mingów, obserwował dramatyczną zmianę panujących. Trudno powiedzieć, w jakiej mierze jego sprawozdanie kształtowała roztropność zręcznego urzędnika, który stojąc na czele rodu, przeszedł pomyślnie przez ten burzliwy okres, a w jakiej chęć samousprawiedliwienia, zwykle zabarwiająca wspomnienia emerytowanych funkcjonariuszy państwowych. Jedno wiadomo na pewno: jego Autorelacja to nie naiwnie szczere wynurzenia autobiograficzne, ale produkt wysoko rozwiniętej kultury politycznej i moralnej. Tak jak wszelkie autobiografie tekst ten wiąże się ze skomplikowanymi kwestiami autentyczności, fikcyjności i prawdy referencyjnej, które

${ }^{32}$ Wu Pei-yi, The Confucian Progress: Autobiographical Writings in Traditional China, Princeton 1990, s. 187-93.

33 Tamże, s. 262. 
tu pozostawiam na boku. Skoncentrujemy się na Wang Shiminie, jaki wyłania się z tej autobiograficznej narracji.

Jak wspomniano, według Taylora wszyscy istniejemy w przestrzeni pytań zadawanych nam przez rozmaitych rozmówców. Dla Wang Shimina takimi rozmówcami są jego współcześni, przełożeni, przodkowie i następcy, mędrcy i sama potomność. Pytania dotyczą tego, kim Wang Shimin jest lub był, a jego odpowiedzi odwołują się do dóbr silnie wartościowanych. Wang pisze, że wczesny okres jego życia naznaczyły dwie „katastrofy”: śmierć ojca i dziadka, w wyniku których jako dziewiętnastolatek zaznał nie tylko poczucia „opuszczenia”, ale także „śmiertelnego niebezpieczeństwa”.

Całe brzemię prowadzenia domu spadło na moje barki, byłem teraz bowiem jedynym mężczyzną w rodzinie. Musiałem zarządzać ogółem spraw domowych oraz radzić sobie ze światem zewnętrznym. Snobizm świata był zaś taki, że dla ocalenia rodziny przed dalszym upadkiem konieczne było, żeby któryś z jej członków osiągnął pozycję i urząd. Tak się złożyło, że w uznaniu zasług mojego dziadka dla kraju zaoferowano mi stanowisko zastępcy naczelnika Urzędu Pieczęci Cesarskich ${ }^{34}$.

Wang patrzy na ów krytyczny moment swojego życia przez pryzmat tego, co ma dla niego najwyższą wagę: przez pryzmat „honoru” rodziny. „Honor” jest w całym jego sprawozdaniu kluczowym dobrem, które tworzy horyzont znaczenia, kontekst implicytnej oceny wszystkich relacjonowanych czynów. Przetrwanie i dobrobyt to dobra uzupełniające, bez wątpienia związane z "honorem”, ale stawianie „przetrwania ponad honor” jest czymś niegodnym, hańbiącym ${ }^{35}$. Nie ulega wątpliwości, że podmiot wpisany w tę narrację jest zorientowany na dobra silnie wartościowane.

Innym konfucjańskim dobrem, które w dużej mierze kształtuje narrację, jest skromna postawa synowska. Wang niemal każde swoje osiągnięcie wiąże z poradami, wpływem lub przykładem ojca i dziadka. Wspomina, że w dzieciństwie obserwował ich powszechnie chwalone zachowanie, słuchał wypowiedzi dziadka i podziwiał erudycyjne dyskusje obydwu na takie tematy, jak kaligrafia i klasycy literatury ${ }^{36}$. Ci bezpośredni przodkowie należą do jego głównych rozmówców, a ich uwagi i przykład stanowią jedną z najważniejszych sieci rozmowy, w których Wang funkcjonuje w ogromnym stopniu jako podmiot relacyjny. Ich słowa bezsprzecznie uformowały jego późniejsze postępowanie. Jako dziecko nieraz słyszał opinię dziadka: „wykształcony urzędnik poza swoim biurem, rezydujący w rodzinnym mieście, powinien za swój pierwszorzędny obowiązek uznać jak najszybszą spłatę podatku i sumienne spełnianie dobrych uczynków. Zanotowałem tę wypowiedź w pamięci i nie zapominałem

\footnotetext{
34 Tamże, s. 253.

35 Tamże, s. 261-262.

36 Tamże, s. 257-261.
} 
o niej dniem i nocą". Dalej Wang relacjonuje, że na emeryturze sam wspomagał ubogich i zawsze starał się jak najwcześniej uiścić podatek ${ }^{37}$.

Ten nieco staroświecki obrazek niewątpliwie ilustruje ogólne podejście Wang Shimina do administracji państwowej z czasów jego urzędowania: chłopiec, który sypiał w pokoju dziadka i usługiwał mu nieustannie, był szkolony do sukcesów w dziedzinie o dużym znaczeniu. Istotnym elementem tego szkolenia było z pewnością wdrażanie do konfucjańskich języków rozeznawania moralnego. Kiedy dziewiętnastoletni Wang otrzymał stanowisko w Urzędzie Pieczęci Cesarskich, wiedział dokładnie, jak ma się zachowywać. Przestrzegał skrupulatnie zasad etykiety (li) i prawości, a wszystkie obowiązki wykonywał „rozważnie i starannie”. Wbrew swoim bezpośrednim interesom zgłaszał się do misji, które wymagały długich, uciążliwych podróży poza dwór cesarski. Świadomy, że posadę zawdzięcza nie tyle własnym osiągnięciom ocenionym przez system egzaminacyjny, ile przychylności władz, chciał „zapobiec szyderstwom, że oto dosta[ł] synekurę"38. W trakcie podróży nie przyjmował podarków i tak obcinał koszty, że gdy po powrocie przedstawiał w biurze rozliczenia, koledzy „wyśmiewali [jego] tępotę”. „Ironizował nawet naczelnik biura. A ja po prostu wiedziałem, że trzeba stosować się do prawa"39. Jego pozornie naiwna sumienność zyskała mu jednak zaufanie i aprobatę szanowanych osób na wyższych szczeblach administracji państwowej. Narrację o swojej karierze Wang kończy opowieścią o rutynowej kontroli prowadzonej przez długoletniego wroga jego rodziny: pomimo drobiazgowej analizy i szukania dziury w całym nie wykryto żadnych uchybień ${ }^{40}$. Takie epizody są dowodem, że surowe wartości, którymi Wang kierował się w życiu, pozwoliły mu przetrwać, a nawet wybić się w bezwzględnym i nieraz wrogim świecie aparatu biurokratycznego.

Wang jawi się dotychczas jako podmiot relacyjny, osoba definiowana przez właściwe odgrywanie ról: jedyny mężczyzna w rodzinie, syn, wnuk i urzędnik, w dokładnie rozrysowanej moralnej przestrzeni wartości konfucjańskich. Niemniej role te nie definiują go całkowicie. Autor opowiada, jakim smutkiem napełniała go myśl, że jego najstarszy brat - zmarły, gdy Wang Shimin miał czternaście lat - nie zostawił po sobie syna, który mógłby sprawować dla niego obrzędy ofiarne. Znalazł niekonwencjonalny sposób zaradzenia tej sytuacji:

Zgodnie z rytuałem kawaler nie może mieć syna adoptowanego pośmiertnie. Doszedłem jednak do wniosku, że rytuał wywodzi się z tego, co słuszne. Przygotowałem zatem oświadczenie i złożyłem je w świątyni przodków, czyniąc mojego

\footnotetext{
37 Tamże, s. 256.

38 Tamże, s. 253-254.

39 Tamże, s. 254.

40 Tamże, s. 255-256.
} 
trzeciego syna Chuana dziedzicem mego zmarłego brata, który dzięki temu będzie odtąd otrzymywał ofiary i libacje ${ }^{41}$.

Słowa na temat rytuału i słuszności nawiązują wyraźnie do mądrości Konfucjusza: „człowiek szlachetny rozpatruje raczej całość niż części. Człowiek pospolity rozpatruje raczej części niż całość” ${ }^{42}$. Zwroty: „doszedłem jednak do wniosku” i „przygotowałem” świadczą natomiast o zakresie osobistej autonomii i sprawczości w rozumowaniu i działaniu, który może wydawać się zaskakujący w świetle stereotypowych poglądów na kulturę konfucjańską. Jak wyjaśnia William Theodore de Bary w Self and Society in Ming Thought, konfucjanista rozpoznaje Drogę w sieci wzajemnych relacji moralnych, ale te nie określaja go w pełni. „W centrum tej sieci istnieje jego wewnętrzne "ja« i tam korzysta ze swojej wolności” ${ }^{43}$. Neokonfucjańskie samodoskonalenie, o jakim tu mowa, zakłada indywidualną sprawczość, wolność i odpowiedzialność. Wang Shimin niewątpliwie przedstawia siebie w tych kategoriach. Tłumacząc, że nie zamierza wchodzić w spór z podstępnymi lichwiarzami, tak uzasadnia swoją postawę moralną i postępowanie:

Od kilkudziesięciu lat uważam, że lepiej jest dla mnie dać się wykorzystać innym, niż samemu ich wykorzystywać, i lepiej jest dla mnie ponosić straty, niż zagarniać nielegalne zyski. Przysiągłem sobie, że nigdy nie odstąpię od tej zasady. Zaświadczy o tym każdy mieszkaniec mojego rodzinnego miasta ${ }^{44}$.

Opisane tutaj „ja” jest sprawczym podmiotem, „aktywnym i samoświadomym bytem” w terminologii Ambrose'a Kinga i Michaela Bonda ${ }^{45}$, definiującym siebie jako jednostkę w kontekście swobodnie podjętej i wprowadzonej niezłomnie w czyn decyzji moralnej.

Na pytanie, kim był Wang Shimin, autobiograf odpowiada tak: był kimś, kto przysiął sobie, że będzie się zachowywać honorowo i należycie, i dotrzymał przysięgi. Inaczej mówiąc, Wang tworzy swoją autobiografię w kategoriach gęstego opisu. Fundamentalne dla jego rozumienia siebie są pojęcia silnie wartościujące, takie jak „honor” i „etykieta”. Definiuje siebie, otwarcie umiejscawiając swoją postawę w przestrzeni moralnej. Pod koniec narracji, spoglądając na minione lata, komentuje: „Nigdy w życiu nie wykroczyłem przeciwko moralności konfucjańskiej”. Jednocześnie zaś jego autodefinicja jest też sprawozdaniem z własnej wartości rozpatrywanej na tle standardów realizowanych przez

${ }^{41}$ Tamże, s. 258.

${ }^{42}$ Konfucjusz, The Analects, 2.14, tłum. S. Leys, New York 1997.

${ }^{43}$ W.Th. de Bary, Self and Society in Ming Thought, New York 1970, s. 149.

${ }^{44}$ Wu Pei-yi, The Confucian Progress: Autobiographical Writings in Traditional China, dz. cyt., s. 257.

${ }^{45}$ A. King, M. Bond, The Confucian Paradigm of Man: A Sociological View [w:] Chinese Culture and Mental Health, red. Tseng Wen-Shing, D.Y.H. Wu, Orlando 1985, s. 31. 
innych. Mimo swoich konfucjańskich cnót Wang Shimin żałuje „nieśmiałości i wewnętrznego niepokoju", jakie przejawiał we wczesnym okresie, inwestując zbyt wiele w pełnienie obowiązków: „Dlatego nie zdołałem dorównać chwale przodków, opanowując jedno dzieło z kanonu klasyków, ani nie zyskałem sławy i nie wyróżniłem się pośród współczesnych, uprawiając jeden kunszt" ${ }^{36}$. Wang wyraźnie interpretuje i ocenia swoje życie w ramach czasowych, które są szersze niż przeżyte przez niego lata.

Przy całym ujawniającym się tu „indywidualizmie” z końcowego okresu Mingów, Autorelacja Wang Shimina nie jest po prostu opowieścią o jednostkowym życiu. Jak powiedzieliśmy, pisano ją z myślą o potomności. Wobec następnych pokoleń, które będą odczytywać ten dokument w świątyni przodków, autor jasno formułuje oczekiwanie, że postarają się „naśladować dawne obyczaje" $\mathrm{i}$,w niczym nie umniejszyć reputacji rodziny” ${ }^{4}$. W tej mierze życie Wang Shimina jest całkiem dosłownie przykładne: poważane przez niego wartości to element rodzinnej „reputacji”, którą potomkowie są obowiązani pielęgnować. Wang pragnie im wpoić odziedziczony po przodkach szacunek dla uczciwości, prawości i etykiety, wierzy bowiem, że „reputacja” rodziny zależy także od kultywowania tych wartości. Jego narracja pokazuje, jak bardzo te dobra były dla niego ważne: pozwoliły mu przetrwać, a nawet odnieść powodzenie w nieprzyjaznym środowisku. Wie z doświadczenia, że sprzyjają one - jak by to ujął Nietzsche - „zachowaniu życia”, zwłaszcza w administracji państwowej, gdzie chwałę rodu łatwo pomnożyć, ale równie łatwo stracić. Troska o honor rodziny bezwzględnie nakazuje, by te wartości przekazywać dalej.

Oczywiście, w narracji Wang Shimina nie ma pokrewieństwa z kolejnymi uwagami Nietzschego, mianowicie że wszelkie wartości, także te konfucjańskie, są filozoficznymi „błędami”, złudną projekcją. Nie ma też śladu neonietzscheańskiej refleksji - a trudno nam ją stłumić przy lekturze Autorelacji-że wartości te były przesiąknięte ideologią i nie tylko nie uwzględniały kobiet i sług umożliwiających funkcjonowanie tego tradycyjnego systemu uczonych o szlachetnym rodowodzie, ale także sankcjonowały ich wyzysk. Jak zobaczymy w następnych rozdziałach, refleksja taka - jakkolwiek byłaby „prawdziwa” - też opiera się na wartościach i silnie wartościowanych dobrach, takich jak należny każdemu szacunek. Wcielanie jej w życie wymaga tych samych procesów namysłu, osądu, oceny ludzi i postępowania, z którymi mierzył się Wang Shimin i z którymi musi się mierzyć każdy człowiek. Do tych właśnie procesów i do uchwycenia sensu naszego życia potrzebujemy gęstych języków wartości i dobra. Jeśli próbujemy się bez nich obyć, jak dowodzi Roland Barthes, życie staje się nieprzejrzyste, a opowieść o nim niemożliwa.

${ }^{46}$ Wu Pei-yi, The Confucian Progress: Autobiographical Writings in Traditional China, dz. cyt., s. 261.

47 Tamże, s. 262. 


\section{Roland Barthes i granice narracji autobiograficznej}

Nietzsche uważał, że pytanie o to, czy jego sceptyczna „prawda” o wartościach daje się wcielać w codzienne życie, ma charakter empiryczny, a odpowiada się na nie „doświadczeniem”. W podobnym duchu Taylor, sceptyczny wobec teorii neonietzscheańskich i postsaussure'owskich, powątpiewa, czy teorie te są w stanie sprostać „testowi” wcielania w życie, czy da się przyjąć ich nieantropocentryczną perspektywę i żyć zgodnie z nią. W zasadzie można twierdzić, że literatura od czasów Dostojewskiego stanowi doświadczenie, do którego nawoływał niemiecki filozof. Jeśli zaś chodzi o Taylora, jednego z testów dostarcza autobiografia awangardowa, w której autorzy próbują opisać swoje życie w językach współczesnych teorii. Najdalej idącą spośród takich prób jest $R o-$ land Barthes. Barthes'owski atak na autorstwo, podmiot, referencyjność językową itd. omawiano już przede mną. John Eakin w Touching the World (1992) dowodzi, że „antyautobiografia” Barthes’a zawiera tak naprawdę wiele cech języka i narracji, które ma podważać, będąc wbrew sobie dziełem referencyjnym $^{48}$. W Threads of Life (2001) ${ }^{49}$ Richard Freadman analizuje sprzeczności tekstu Barthes'a w relacji do woli. Obaj badacze rozpatrują to jako przypadek graniczny, wykazując konieczność pewnych cech konstytutywnych autobiografii, otwarcie przez Barthes'a odrzucanych: Eakin pisze o referencyjności, Freadman o sprawczości. Pójdę podobną drogą, koncentrując się jednak na konieczności bycia podmiotem w przestrzeni moralnej. Tu Roland Barthes również jest przypadkiem granicznym, który świadczy, że przy swoim nastawieniu do wartości Barthes nie może się całkowicie obyć bez silnie wartościowanych dóbr i warunkowanej przez nie potrzeby uchwycenia sensu swojego życia jako toczącej się opowieści. W kluczowych momentach rzadki antyhumanistyczny język postawy teoretycznej zanika wobec nieuchronnego umiejscawiania się w przestrzeni moralnej. Barthes powraca wtedy do gęstszych języków rozumienia siebie oraz do struktury autobiograficznej, która ujawnia się mimo jego usilnych starań, by ją stłumić.

Roland Barthes przedstawia swoje podejście do wartości jako niejednoznaczne. $Z$ jednej strony jest to „długi tekst o wartości, o emocjach związanych Z wartościowaniem - co pociąga za sobą aktywność etyczną i zarazem semantyczną". Z drugiej strony, jest w nim ,energia równająca się marzeniu o »definitywnym obaleniu rządów wartości "" ${ }^{50}$. Niejednoznaczności takie są w tym tekście programowe jako element przyjętej dialektycznej metody badawczej. Ta konkretna niejednoznaczność ma tu jednak szczególną wagę: w tabeli prezentującej „fazy” kariery „R.B.” czytamy, że „gatunkiem” książki jest moralité,

\footnotetext{
48 J. Eakin, Touching the World, Princeton 1992, s. 14-23.

${ }^{49}$ R. Freadman, Threads of Life: Autobiography and the Will, Chicago 2001, s. 114-116.

${ }^{50}$ R. Barthes, Roland Barthes, tłum. T. Swoboda, Gdańsk 2011, s. 166.
} 
a jej „intertekstem” - „(Nietzsche)”51 .,R.B.” przyznaje, że pisząc ten tekst, był przesiąknięty Nietzschem, dlatego aktywność etyczna i zarazem semantyczna - ujmowana często w lapidarnie epigramatycznych fragmentach, takich jak „Obalenie rządów wartości” cytowane powyżej - nie zaskakuje. Jeśli uwzględnić rolę Nietschego jako głównego rozmówcy, nie dziwi także widoczna w tekście mieszkanka głębokiego sceptycyzmu etycznego i nowatorskiej refleksji. We fragmencie zatytułowanym „Między Salamanką a Valladolid” Barthes tak kreśli nową filozofię moralną, którą nazywa „preferencjalizmem”:

Któregoś letniego dnia (1970), kursując i marząc między Salamanką i Valladolid, dla zabicia nudy wymyślił sobie nową filozofię, od razu ochrzczoną „preferencjalizmem", nie troszcząc się wówczas zbytnio w swoim samochodzie, czy jest lekkomyślna, czy może winna: na materialistycznym tle (na skale?), gdzie świat widoczny jest jako tkanina, jako tekst opowiadający językową rewolucję, wojnę systemów, a rozproszony, nieukonstytuowany podmiot może się uchwycić tylko w porządku wyobrażenia, wybór (polityczny, etyczny) tego niby-podmiotu nie ma żadnej założycielskiej wartości: wybór ten nie jest ważny; niezależnie od tego, czy ogłaszamy go z namaszczeniem czy przemocą, nie jest niczym więcej niż tylko skłonnością: wobec kawałków świata mam prawo wyłącznie do preferencji ${ }^{52}$.

Rozproszony podmiot postmodernistyczny, w którym nie ma zadomowionego wewnątrz, skoncentrowanego „ja”, lecz jest - tu zgrabna Barthes'owska gra słów - dosłownie personne ${ }^{53}$, nie może dokonać żadnego wyboru darzącego go egzystencjalnym bytem. Bez względu na to, jak istotny był kiedyś dla Barthes'a Jean-Paul Sartre, jego myśl jest elementem czegoś, co od tamtej pory „zdekonstytuowano” na wojujące ze sobą „systemy” językowe. Jednocześnie zaś w całym Rolandzie Barcie myśl Sartre'a pozostaje istotna, bo Barthes wciąż zakłada, że bez radykalnego wyboru etycznego lub politycznego nie ma dla „nibypodmiotu” żadnej „założycielskiej wartości”, a tylko le néant, nicość. Z perspektywy filozoficznej świat i podmiot to nic więcej jak „kawałki”, czytelne jedynie w obrębie wielkiego tekstu systemów językowych. Wybór egzystencjalny, podobnie jak spójne „ja”, jest złudzeniem, częścią lacanowskiego imaginarium, które nadaje mu tutaj formę „porządku wyobrażenia” - aby wziąć go w cudzysłów lub przypisać trzeciej osobie, jakiemuś „jemu”, nie bardziej rzeczywistemu niż postać z powieści.

Innymi słowy, jeśli brakuje egzystencjalnego wyboru, który by „założył” podmiot przez byt, a świat przez wartość, pozostaje jedynie „preferencja”. Barthes wyczuwa, o jaką stawkę toczy się tu gra: zdekoncentrowany podmiot nie może mieć na trwałe żadnego wartościującego zaangażowania - żadnego,

51 Tamże, s. 157.
52 Tamże, s. 171.
53 Tamże, s. 132. 
które czyni jedną preferencję bardziej godną uznania od drugiej - lecz tylko „kkłonności” lub pewne upodobania i antypatie, takie jak te wymienione w „Lubię, nie lubię" ${ }^{54}$. Dla Taylora oznacza to dokładnie, że mogą istnieć jedynie słabe wartościowania, ponieważ nie ma niczego, co preferencjom, skłonnościom i upodobaniom postmodernistycznego podmiotu nadawałoby większą wagę, wartość lub znaczenie niż temu, czego podmiot nie lubi i nie preferuje. W żartobliwym komentarzu do ukazanego w ten sposób „preferencjalizmu” Barthes umieszcza pytania sprawdzające rozumienie tekstu, a jedno z nich brzmi: „Podaj filozofie, które można by przeciwstawić "preferencjalizmowi«" 55 . Jeżeli do takich filozofii należy egzystencjalizm, na pewno jest wśród nich też filozofia moralna Taylora, oparta na nieuniknionej konieczności silnego wartościowania. Ponownie nasuwa się tu Taylorowska wątpliwość jako test empiryczny: preferencjalizm łatwo głosić jako teorię, ale czy można zgodnie z nim żyć?

Nie mamy niezapośredniczonego dostępu do życia Barthes'a, nie możemy więc tak po prostu poddać go temu testowi. Możemy natomiast zbadać język, w którym Barthes pisze swoje życie albo odmawia jego pisania. Badanie pokaże, w jakiej mierze da się przekonująco pisać o sobie i swoim życiu, posługując się wyłącznie językiem słabych wartościowań. Jak powiedziałem, Barthes czuje, o jaką stawkę toczy się gra. Wie, że to, co nazywamy silnym wartościowaniem, podważa popierane przez niego stanowisko, i dlatego bardzo się stara unikać języka wyboru egzystencjalnego. W „Sed contra” ${ }^{56}$, na przykład, przedstawia swój dialektyczny proces rozumowania w Rolandzie Barcie tak, by takiego języka nie dało się zastosować. Jak czytamy, „R.B.” często rozpoczyna namysł od jakiegoś stereotypu, od pospolitej opinii, którą w sobie dostrzega. Następnie zwraca się przeciwko niej - nie z tego powodu, że jest jakoś gorsza albo mniej sensowna od innych: „Szuka czegoś innego właśnie dlatego, że jej nie chce (wskutek estetycznej czy też indywidualistycznej reakcji); zazwyczaj szybko się męczy i po prostu zatrzymuje na opinii przeciwnej, na paradoksie, na czymś, co mechanicznie podważa przesąd". Jak widzimy, podkreślono tu zręcznie zwróćmy uwagę na objaśniający nawias - słaby charakter wartościowania: pospolite opinie nie są „,hciane” ze względu na swoją estetyczną nieatrakcyjność lub jakiś indywidualistyczny kaprys - trudno rozstrzygnąć. W każdym razie samo preferowanie antytezy to zaledwie „reakcja”, „mechaniczne” podważanie stereotypu. Dialektyczny ruch myśli ma charakter systemowy: na jednym poziomie przebiega w mózgu, na drugim w tekście ścierających się z sobą języków, a niezaangażowany podmiot postrzega go tylko jako nieco męczący proces, ewentualnie jako „intelektualny (...) »sport". Podmiot może także dbać, jak kucharka, po prostu o to, by „język nie wykipiał, żeby nie przywarł”. Jest to, jak komentuje Barthes, „czysto językowa taktyka, strzelająca w powietrze,

\footnotetext{
54 Tamże, s. 128-129.

55 Tamże, s. 171.

56 Tamże, s. 174-177.
} 
poza wszelki strategiczny horyzont”. Teraz jednak pojawia się w tej prozie coś dziwnego. Logika była do tej pory następująca: za stereotypem podąża się aż do osiągnięcia jego przeciwieństwa i jest to jedynie mechaniczna „taktyka”. Tymczasem pod koniec „Sed contra” pada pytanie: „a co zrobić, jeśli stereotyp przejdzie na lewo?”. W takiej sytuacji - można przypuszczać - reakcją będzie skręt myśli w prawo, co też nie powinno być istotne, jeśli pisze się tekst dla samych tylko preferencji estetycznych, bez strategicznego horyzontu. Barthes natomiast tak tego nie przedstawia: „Niebezpieczeństwo polega na tym, że stereotyp przemieszcza się na płaszczyźnie historycznej i politycznej, więc trzeba za nim wszędzie gonić”. Skąd wzięło się tu „niebezpieczeństwo”? Czemu reakcja na tę możliwość miałaby się wiązać z jakimś znaczeniem?

Barthes jest dostatecznie szczwany - cały czas o krok wyprzedza analizę, jaką tu prowadzę - by wiedzieć, że taka niejednoznaczność równa się aporii ${ }^{57}$ w jego tekście. Godne zaś uznania jest u niego to, że przy swoim uporczywym, acz stylowym, zaangażowaniu teoretycznym ma w sobie autentyczną otwartość na aporię i jej konsekwencje. Krótko mówiąc, bywa chwilami gotów pozwolić sobie i nam dostrzec, że coś jednak ma znaczenie. Widać to jaśniej we fragmencie „Naturalność”. Jak czytamy, naturalność to „złudzenie (...) nieustannie podważane” przez niego we wcześniejszych pracach jako „alibi społecznej większości" ${ }^{58}$. I tu nagle Barthes staje się - na swój wymyślnie antyautobiograficzny sposób - autobiograficzny:

Źródeł tej krytyki należy szukać w mniejszościowej sytuacji samego R.B.; zawsze należał on do jakiejś mniejszości, do marginesu - społeczeństwa, języka, pragnienia, zawodu, a dawniej również religii (miało swoją wagę bycie protestantem w klasie katolików); nie jest to sytuacja bardzo dokuczliwa, lecz znamienna dla całego społecznego istnienia: któż nie czuje, jak czymś naturalnym jest we Francji bycie katolikiem, mieć małżonka i dobry dyplom? Najmniejszy brak w tej tabeli publicznych stosowności tworzy rodzaj cienkiej fałdy w tym, co moglibyśmy nazwać społeczną ściółką ${ }^{59}$.

Barthes od razu asekuruje się typowymi dla siebie środkami: jest to doświadczenie „R.B.” przedstawione w trzeciej osobie, i podobnie jak resztę tekstu należy je „uznać za wypowiedziane przez postać z powieści” ${ }^{60}$. Nie jestem jednak pierwszym

57 W filozofii greckiej aporia to impas, z pozoru nierozwiązywalna trudność, od której powinna się zaczynać refleksja filozoficzna. W myśli postmodernistycznej aporia ma węższe znaczenie: odnosi się do tego momentu dekonstrukcjonistycznej argumentacji, gdy analiza ukazuje tekst jako wewnętrznie sprzeczny, obalający opozycje binarne, na których właśnie został zbudowany. Używam tutaj terminu aporia w tym drugim sensie - jako ironicznej wskazówki, że postmodernistyczny tekst Barthes'a podważa sam siebie.

${ }^{58}$ R. Barthes, Roland Barthes, dz. cyt., s. 142-143.

59 Tamże, s. 143.

${ }^{60}$ Tamże, początek książki bez numeru strony. 
czytelnikiem, dla którego te zdania brzmią bynajmniej nie powieściowo, lecz autobiograficznie $^{61}$. Barthes'owska krytyka tego, co „naturalne”, ma swoje spekulatywne źródło w marginesowości, którą Barthes odczuwał niegdyś i nadal odczuwa jako mającą „swoją wagę” w katolickiej i mieszczańskiej Francji. Słychać to w jego pytaniu retorycznym: „któż nie czuje, jak czymś naturalnym jest we Francji (...)?”. Przez całe dorosłe życie sprzeciwiał się zbiorowemu przypisywaniu norm społecznych iluzorycznej „naturze” i piętnował jego arbitralność. Jest w tym coś więcej niż skłonność estetyczna czy zwykła „preferencja”, coś więcej niż poczucie moralne. Naturalność jest nie tylko arbitralna: instytucjonalizuje uprzedzenia. Bunt przeciwko niej przez „awangardowe, transgresyjne działanie” to nie kwestia tymczasowego „nastroju”, jak sugeruje nam się nieco dalej, lecz kwestia wieloletniego zaangażowania. Chociaż sam Barthes nie może tego tak określić, chodzi tu o poczucie sprawiedliwości, o domaganie się równego szacunku dla wszystkich, czyli silnie wartościowanego dobra, do którego nawiązuje ten fragment i duża część książki.

Taylor argumentuje między innymi, że zauroczenie naturalizmem nie pozwala dzisiejszym ludziom Zachodu - w przeciwieństwie do uczonych urzędników z końca panowania Mingów - rozpoznawać i wskazywać dóbr, jakimi kierują się w życiu. Jak zobaczymy w następnych rozdziałach, silnie wartościowane dobra związane z tekstem autobiograficznym trzeba odsłaniać za pomocą swego rodzaju dekonstrukcjonistycznej analizy, tak by wydobyć etyczną wymowę momentów aporetycznych. Niekiedy wymaga to czytania tekstu wbrew niemu samemu - i tak właśnie jest w przypadku Barthes’owskiego „preferencjalizmu”. Przede wszystkim warto przyjrzeć się tezie, że „R.B.” zależnie od swoich inklinacji jest w stanie cieszyć się poczuciem przynależności społecznej albo ją odrzucać, jak dowiadujemy się z ostatnich zdań „Naturalności”:

On jednak zdaje się dziwnym sposobem stać na skrzyżowaniu tych dwóch dróg: miewa skłonności do transgresji, ale i nastroje indywidualistyczne. Owocuje to racjonalną w gruncie rzeczy filozofią anty-Natury, a idealnym przedmiotem dla takiej filozofii jest Znak: można bowiem potępiać i/lub opiewać jego arbitralność; można rozkoszować się kodami, z rozrzewnieniem wyobrażając sobie dzień, w którym zostaną obalone: niczym okresowy outsider mogę wkraczać w trudną społeczną komunikację lub ją porzucać, zależnie od nastroju - włączać się bądź dystansować ${ }^{62}$.

Oczywiście, logika jest tu bardziej kręta, niż ją dotychczas prezentowałem: „opiewanie” arbitralności Znaku to niezupełnie to samo co „rozkoszowanie się kodami”, a rozkoszowanie się nimi nie musi oznaczać wkroczenia w społeczną komunikację. Czytając jednak o włączaniu się i dystansie zależnych od

${ }^{61} \mathrm{~W}$ Touching the World John Eakin pisze o wielu czytelnikach, którzy w takich momentach zauważają ten sam paradoks: „Barthes wbrew sobie jawi się jako autobiograf”, s. 17.

${ }^{62}$ R. Barthes, Roland Barthes, dz. cyt., s. 143. 
nastroju, o okresowym outsiderze, odnoszę wrażenie, że mamy tutaj do czynienia z wprawnym preferencjalistą, który zaciera za sobą ślady. W pewnym sensie każde słowo może być „prawdziwe”. Nie jest nie do pomyślenia, że „R.B.” potrafi się przerzucać z jednej pozycji na drugą tak, jak to opisuje. Trudniej uwierzyć, że za tymi fluktuacjami nie kryje się jakaś trwała tożsamość, jakaś struktura poczucia moralnego zbudowana na długoletnim oporze przeciwko „naturalności” i na całożyciowym postrzeganiu siebie jako „outsidera”. Wobec takich powracających i silnie odczuwanych kwestii „R.B.” wyłania się z tej narracji jako podmiot w przestrzeni moralnej.

Nie jestem też pierwszym czytelnikiem, któremu „Naturalność” współbrzmi z fragmentem zatytułowanym „Wspomnienie z dzieciństwa”63.

Kiedy byłem dzieckiem, mieszkaliśmy w dzielnicy zwanej Marrac; stawiano w niej mnóstwo domów, a na placach budowy bawiły się dzieci; w glinie wydrążono wielkie dziury, w których miały spocząć fundamenty, i któregoś dnia, po zabawie w jednej z takich dziur, wydostały się z niej wszystkie dzieciaki poza mną; z góry, z powierzchni ziemi, naigrywali się ze mnie: byłem przegrany! sam! na oczach wszystkich! wykluczony! (być wykluczonym nie znaczy być na zewnątrz, lecz być samemu w dziurze, zamkniętym pod otwartym niebem: wyłączonym); wtedy przybiegła moja matka; wyciągnęła mnie i zabrała daleko od dzieci, przeciwko nim ${ }^{64}$.

Jeśli pominąć fotografie, jest to jeden z bardzo niewielu elementów Rolanda Barthes'a, który ma charakter autobiograficzny - w tym sensie, że nie znajdujemy w nim dyfrakcji dyskursu za pomocą przesunięć zaimkowych czy nominalnie na wpół fikcyjnego „R.B.”. Nie pojawia się tu również preferencjalistyczny metadyskurs, który by maskował pełną udręki bezradność przebijającą ze słów: „przegrany! sam! na oczach wszystkich! wykluczony!”. Pomimo antynarracyjnej formy tekstu jako całości widoczne jest co najmniej pokrewieństwo między tym epizodem a poczuciem wykluczenia, jakiego Barthes doznawał w katolickiej, mieszczańskiej i heteroseksualnej Francji. Nie trzeba też szukać teleologicznych powiązań, by dostrzec w obu fragmentach znamiennie podobne opozycje: samotność a grupa, wykluczenie a przynależność, różnica a identyczność. Jest tu także rodząca się świadomość przytłaczającej mocy większościowego stanowiska, określanego przez Barthes'a jako „Doksa” - ortodoksja. O tyle, o ile można uważać ten fragment za element narracji tożsamościowej, dziecko tkwiące w dziurze niewątpliwie doświadcza, czym jest bycie „outsiderem”. Tożsamość tę w jakiejś mierze potwierdza matka, kiedy ratuje syna i zabiera go z dala od dręczycieli - „przeciwko nim” ${ }^{65}$.

${ }^{63}$ John Eakin w Touching the World cytuje ten fragment $\mathrm{z}$ analogicznych powodów.

${ }^{64}$ R. Barthes, Roland Barthes, dz. cyt., s. 133-134.

${ }^{65}$ Opór Barthes’a wobec autobiografii słabnie szczególnie właśnie wtedy, gdy mowa o matce, a wydaje się kompletnie złamany w książce Światto obrazu. Uwagi o fotografii. Ten poruszający 
To, od czego Roland Barthes stroni w narracji, odkrywamy w swoistej mozaice fragmentów, „porządku wyobrażenia”, który ukazuje tożsamość przez formy reakcji i refleksji - oraz przez występujące w nich anomalie. Bezradne dziecko przeciwstawione dominującemu stanowisku grupy znajduje echo w dorosłym, który rozważa przeróżne tematy, w tym „naturalność” i uciążliwe „trzy rodzaje arogancji”: arogancję typową „dla Nauki, dla Doksy i dla Bojownika” („Doksa” to „Opinia publiczna, Duch większości, drobnomieszczański Konsensus, Głos Natury, Gwałt Przesądu” ${ }^{66}$. „Arogancja” jest terminem gęstego opisu etycznego, deskryptywnym, a zarazem wartościującym, którego Barthes używa, by wyartykułować swoją reakcję na upokarzające człowieka „Zwycięskie dyskursy” ${ }^{67}$. Terminy takie umiejscawiają go jednocześnie w przestrzeni moralnej. Poprzez swoją postawę wobec arogancji i upokarzania Barthes ujawnia, jak postrzega samego siebie: jest kimś, kto sprzeciwia się wszelkim bojowym dyskursom, nie wyłączając dyskursu politycznej lewicy, ponieważ nieuchronnie w kogoś uderzają. Dyskursy te dzielą z nauką i rozmaitymi ortodoksjami arogancką potrzebę, by mieć ostatnie słowo albo być ostatnim słowem w każdej dziedzinie, także w dziedzinie języka. Tu Barthes definiuje siebie również przez dystansowanie się od niektórych swoich głównych rozmówców z przeszłości: Karla Marksa, Bertolta Brechta i Jeana-Paula Sartre'a. Narzeka, że lewicową politykę „uznaje się za podstawową naukę o rzeczywistości” i obdarza się ją „,wielką mocą: zdolnością poskramiania języka, sprowadzania jego gadulstwa do resztek rzeczywistości”. Odwraca sytuację, traktując taką politykę po prostu jako język - język, który powtarza się monotonnie jako zwykła „paplanina” i przekształca się w „długi orszak nieruchomych zdań" ${ }^{6}$.

Barthes umiejscawia siebie moralnie w relacji do dwóch typów mocy nadawanej językowi. Jest przeciwny wszelkim głuszącym dyskursom, które uzurpują sobie „wielką moc” nad innymi, a staje po stronie ekstatycznej mocy wyrażającej się w „dreszczu sensu” ${ }^{69}$. Dreszcz taki, związany z czymś, co Barthes określa jako „moralność znaku”, pozwala się odczuć wtedy, gdy „złudzenie (znienawidzone) oczywistości łuszczy się, pęka, językowa maszyna zostaje uruchomiona”, i gdy sens, zanim ,zniknie w braku znaczenia, jeszcze drży: jest jakiś sens, lecz nie da się go "uchwycić«; pozostaje płynny, nosi ślad lekkiego wzburzenia”70. Znak jest „moralny”, dopóki nie popadnie w reifikację ortodoksji lub nie zostanie w wyniku powtórzeń „bezlitośnie zagarnięty przez sens stały” dyskursu

pamiętnik napisany po śmierci matki brzmi jak pełna skruchy palinodia wobec całej intelektualnej drogi Barthes'a.

${ }^{66}$ R. Barthes, Roland Barthes, dz. cyt., s. 57.

67 Tamże.

${ }^{68}$ Tamże, s. 64.

${ }^{69}$ Taki w dużej mierze jest Barthes z Przyjemności tekstu, zarówno jeśli chodzi o faworyzowanie jouissance, jak i o wyrzeczenie się finalizującej formy dyskursywnej i narracyjnej.

${ }^{70}$ R. Barthes, Roland Barthes, dz. cyt., s. 109. 
bojowego $^{71}$. Mamy tu postromantyczną, ekspresywistyczną wersję dobrego stanu rzeczy: aprobatę zrywania nawarstwień swojskiej myśli, rozłupywania zaskorupiałych granic znaczenia, przedzierania się do „świeżości języka”72. Jest to jednocześnie moralność romantyczna z odcieniem lacanowskim: swojskie granice stanowią imaginarium, ideał „ja”, z którego dreszcz sensu i jouissance obiecują ucieczkę. W moralności znaku kryje się zatem naprawdę niemało.

By uznać dreszcz sensu za coś lepszego od monotonnego powtarzania iluzorycznych stałości ortodoksji, nie wystarczy chwilowa skłonność czy preferencja. Perspektywa utraty mocy twórczej łączy się z lękiem. We fragmencie zatytułowanym „Wyobrażenia samotności” czytamy, że dawniej praca postępowała zawsze „pod auspicjami jakiegoś wielkiego systemu (Marksa, Sartre’a, Brechta, semiologii Tekstu)", teraz zaś jest bardziej niezależna. Tu następuje wyznanie:

Mówi o tym (...), by wyjaśnić samemu sobie obecne poczucie niepewności, a zwłaszcza kłopotliwą udrękę, jaką sprawia mu powrót do znikomości, do niedzisiejszej rzeczy, którą jest, „pozostawiony samemu sobie”.

- Składa tu pan deklarację pokory; nie wychodzi pan więc poza porządek wyobrażenia, i to najgorszego z możliwych: psychologicznego. To prawda, że za pomocą tego zwrotu, którego pan nie przewidział i bez którego mógłby się obejść, potwierdza pan słuszność swojej diagnozy: faktycznie, idzie pan wstecz. - Ależ mówiąc to, wymykam się... i tak dalej (wypustka ciagnie się dalej) ${ }^{73}$.

Mamy tu całą paradę osób gramatycznych: trzecioosobowy „on” przyznaje się do „udręki” na myśl o „powrocie” do „niegdysiejszej rzeczy”, jaką tworzył, zanim zaczął pracować pod egidą wielkich systemów; druga osoba jako „pan” komentuje autorefleksyjnie, że takie deklaracje „pokory” nie tylko nie pozwalają na ucieczkę z imaginarium, ale wręcz świadczą o diagnozowanym przez nie cofaniu się; pierwszoosobowe „ja” odpowiada, że sam akt diagnozy oznacza tego rodzaju transcendentny wgląd, którego nie można pogodzić z regresem. Myślowa „wypustka” pnie się więc dialektycznie w górę. Oczywiście, w ukazanym ciągu jest coś, co sugeruje niekończący się proces - taką wymowę ma „i tak dalej" - a zarazem widać dośrodkowy ruch od refleksji w trzeciej osobie do refleksji pierwszoosobowej. Biorąc pod uwagę pogląd Barthes'a na subiektywne wnętrze, tego drugiego aspektu nie sposób zbyt mocno podkreślić. Niemniej jest tu wrażenie myśli posuwającej się naprzód, tak że termin „dialektyka” wydaje się jak najbardziej stosowny.

Skoro tak, dwie rzeczy rzucają się w oczy. Po pierwsze, cytowane słowa wskazują na troskę Barthes'a o to, w jakim punkcie życia teraz się znajduje. Najpierw

\footnotetext{
71 Tamże, s. 109-110.

72 Tamże, s. 101.

73 Tamże, s. 114.
} 
czytamy o „poczuciu niepewności” i „kłopotliwej udręce” wywołanych refleksją nad sobą porównywanym z sobą z przeszłości. Później przychodzi pokrzepiające stwierdzenie, że w jakimś sensie musi się tutaj dokonywać ruch w górę. Odkrycie, że jednak nastąpił regres, niewątpliwie nie byłoby dla Barthes’a obojętne. Jak mówiłem, stawką jest tu coś więcej niż zwykła preferencja. Można być i można się stać kimś wyższym albo niższym, jest praca znikoma i praca znacząca. Przy całej asekuracji i dystansującej się gramatycznej żonglerce osobami jest to język silnych wartościowań. Mamy oto sześćdziesięcioletniego człowieka, który wyjawia swoje konstytutywne zainteresowania, próbując się umiejscowić w przestrzeni wartości naprawdę dla niego istotnych. Poprzez szczeliny $\mathrm{w}$ jego stylowo preferencjalistycznym metadyskursie przebłyskuje nam podmiot w przestrzeni moralnej. Także tutaj przebłyski są aporetyczne.

Po drugie, ów aporetyczny zapis dowodzi, że Barthes zauważa w swoim życiu pewien kierunek. Wyrażone w pierwszej osobie „wymknięcie się" z regresu jest aktem pojemnego wglądu, który oznacza postęp myśli: otuchę w „udręce” przynosi refleksja, że w jakimś sensie idzie się naprzód. Jest to moment aporetyczny, cały tekst bowiem zaprojektowano jako „krąg fragmentów”, z których każdy jest początkiem, żaden końcem: „(nie lubi za to końców: ryzyko retorycznej klauzuli jest zbyt wielkie: lęk, że nie będzie potrafił oprzeć się ostatniemu słowu, ostatniej replice)”. Oczywiście, początek kojarzy się z moralnością znaku, świeżością języka, a koniec z zamknięciem, agresywnym obstawaniem przy tym, że jest to ostatnie słowo. Jak czytamy, „niespójność lepsza jest od porządku, który zniekształca" "74. Oto głębszy motyw, dla którego Barthes wyrzeka się narracji autobiograficznej: narracja taka sugeruje objaśnieniową przewagę starszego „ja”, opowiadającego, nad opowiadanym młodszym „ja” - przewagę iluzoryczną, bo zawsze otwartą na dalszą „,interpretację”.

Książka ta nie jest księgą „wyznań”; nie dlatego, że jest nieszczera, lecz dlatego, że nasza wiedza jest dziś inna niż wczoraj; wiedzę tę można streścić tak: to, co o sobie piszę, nigdy nie jest ostatnim słowem: im bardziej jestem „szczery”, tym łatwiej poddaję się interpretacji innych instancji niż te, którym podlegali dawni autorzy, wierzący, że ich jedynym prawem jest autentyczność. Instancjami tymi są Historia, Ideologia i Nieświadomość. Moje teksty, otwarte (jakże mogłoby być inaczej?) na te różne rodzaje przyszłości, zrywają wzajemne zależności, jeden nie skrywa drugiego; ten nie jest niczym innym jak tylko kolejnym tekstem, ostatnim z serii, ale nie niosącym ostatecznego sensu: tekst o tekście - to nigdy niczego nie wyjaśnia.

Jakim prawem moja teraźniejszość miałaby mówić o mojej przeszłości? Czy moja teraźniejszość ma przewagę nad przeszłością? Jakaż „łaska” miałaby mnie oświecić? Wyłącznie napotkana na drodze łaska mijającego czasu albo dobrej sprawy?75

\footnotetext{
${ }^{74}$ Tamże, s. 105-106.

75 Tamże, s. $132-133$.
} 
Barthes świadomie dystansuje się od autobiograficznej tradycji Augustyna i Rousseau, wysuwając standardowy zarzut postmodernizmu: narracja autobiograficzna, niezależnie od tego, jak bardzo autobiograf stara się być „autentyczny" wobec własnego doświadczenia, pozostaje otwarta na objaśnieniową analizę rozpatrującą determinizmy historii, języka bądź układu sił, z których piszący może nie zdawać sobie sprawy. Barthes nie twierdzi, że taka analiza jest słuszna czy prawdziwa. Chodzi mu raczej o to, że wyłania się z niej inna opowieść - a kto rozstrzygnie, co powinno mieć tu ostatnie słowo?

W tym momencie warto znowu przywołać Taylorowską zasadę „najlepszego objaśnienia" i zapytać, dlaczego mielibyśmy rezygnować z pierwszoosobowej narracji tylko na tej podstawie, że da się wygenerować dowolną liczbę alternatywnych objaśnień w trzeciej osobie. Pytamy o to, ponieważ - jak dowodzi przykład samego Barthes'a - objaśnienia takie nie są w stanie zadowolić podmiotu, który próbuje zrozumieć własne życie jako opowieść pierwszoosobową. Barthes jako teoretyk znaku może kwestionować „prawo” swojej teraźniejszości do rozważań nad swoją przeszłością i do przypisywania sobie ostatniego słowa w tej sferze. Sześćdziesięcioletni człowiek Barthes natomiast czuje potrzebę namysłu nad tym, dokąd i jaką drogą zmierza jego życie, nad miejscem, jakie sam zajmuje w relacji do swojego młodszego ,ja”. Na takie pytania odpowie jedynie narracja autobiograficzna, niezbędna - jak sądzi Taylor - dla człowieka jako bytu, który rozwija się i staje: „mogę znać samego siebie tylko poprzez moją historię dojrzewania i regresji, historię zwycięstw i klęsk. Moje samorozumienie ma z konieczności czasowy wymiar i opiera się na narracji”" Teraźniejszość jest więc „uprzywilejowana” w narracji autobiograficznej wyłącznie jako punkt widzenia, który nieuchronnie obieramy, próbując obecnie zrozumieć siebie w stosunku do tego, czym byliśmy i jak staliśmy się tacy, jacy jesteśmy. $\mathrm{Z}$ mojego punktu widzenia - choć inni nie muszą się ze mną zgadzać - nie ulega wątpliwości, że teraz rozumiem siebie lepiej niż kiedyś, bo mój obecny ogląd obejmuje mnie takiego, jaki byłem dawniej. Jak zauważa Barthes, regres rozumiany jako regres świadczy o swego rodzaju transcendencji regresu. Właśnie dlatego „wypustka ciągnie się dalej”. Nie może być inaczej.

Nie może być inaczej, bo - jak mówi Taylor - jesteśmy w stanie zrozumieć własne życie tylko jako rozwijającą się narrację. Barthes oczywiście temu zaprzecza, ponieważ ze swojej semiologicznej perspektywy postrzega podmiot jako rozproszony, jako zwykłą „mozaikę reakcji” bez czegokolwiek „pierwotnego". Wszystko, czym człowiek może być, przesuwa się w zawrotnej sekwencji, zajmując „miejsce w każdym pasku widma”. Barthes cytuje Diderota: „Wszystko dokonało się w nas, bośmy sobą, wciąż sobą, i ani przez chwilę tacy sami”"77. Mimo to, jak argumentowałem, w Rolandzie Barcie coś „pierwotnego” wciąż daje się zauważyć. Barthes - o ile nie posługuje się paradoksami - nigdy nie

\footnotetext{
${ }^{76}$ Ch. Taylor, Źródta podmiotowości. Narodziny tożsamości nowoczesnej, dz. cyt., s. 100.

77 R. Barthes, Roland Barthes, dz. cyt., s. 155-156.
} 
opowie się za „naturalnością”, „Doksą" i „normalnością” w przeciwstawieniu do transgresji outsidera, nigdy nie przedłoży bojowej reifikacji nad dreszcz sensu ani ostatniego słowa nad świeży początek, co oznacza, że nigdy nie wykroczy przeciwko „moralności znaku”. W tekście stale pobrzmiewa poczucie moralne związane z pewnymi obszarami znaczenia. Gdy więc czytamy o „fazach” twórczości, o pracy pod auspicjami André Gide’a, Sartre’a, Marksa, Brechta, Ferdinanda de Saussure'a, Philippe’a Sollersa, Julii Kristevej, Jacques’a Derridy, Jacques'a Lacana i na koniec Nietzschego, trudno nam traktować tak przedstawioną sekwencję jako czysto mechaniczną „reakcję” typu „klin wybije klina”. Rzecz jasna, Barthes odrzuca narrację według „faz ewolucji”, bo czyniłaby go „pojmowalnym”, stanowiąc „działanie fikcyjne” w sensie lacanowskim ${ }^{78}$. Gdzie indziej jednak mówi, że jego twórczość „ewoluuje (...) od morale zaangażowania do moralité znaczącego" "79. Wskazuje to na rozwój dokonujący się przez wypieranie jednej rzeczy przez drugą - rozwój, o jakim świadczy cały ten tekst. Barthes raz po raz spogląda na minione „fazy”, na przykład egzystencjalizm i marksizm (jak wynika z jego nastawienia do „autentyczności” i „naturalności”), z poczuciem, że z nich wyrósł. W takich momentach widać, że - podobnie jak my wszyscy - rozumie swoje życie jako toczącą się narrację: nie tylko jako opowieść o arbitralnych, mechanicznych „reakcjach”, ale także o istotnych aktach - aktach namysłu nad znaczeniem swoich kolejnych rozmówców i intelektualnych zależności, aktach analizowania ich ograniczeń i przechodzenia dalej.

Autor Rolanda Barthes'a jest na jakimś poziomie świadomy siły argumentów, jakie tutaj przedstawiam. Przyznaje, że ostatecznie nie udaje się zrealizować zamierzeń związanych z jego mozaikowym tekstem. Metakomentarz okazuje się zaledwie retorycznym naciskiem położonym na coś, czego koniec końców nie można osiągnąć:

Mam złudzenie, że kawałkując swoją wypowiedź, przestaję tworzyć wyobrażenie samego siebie, zmniejszam ryzyko transcendencji; ponieważ jednak fragment (haiku, maksyma, myśl, kawałek gazety) jest właściwie gatunkiem retorycznym, a retoryka jest tą warstwą języka, która najlepiej poddaje się interpretacji, to w takim razie kiedy sądzę, że rozpraszam własną osobę, tak naprawdę posłusznie podporządkowuję się wyobrażeniu ${ }^{80}$.

Mozaikowe fragmenty nie przynoszą nic poza złudzeniem, że „podmiot to tylko efekt języka" ${ }^{1}$, rozproszony wśród swoich różnorodnych tekstowych powtórzeń. Nie są natomiast w stanie unicestwić opowiadanej tożsamości, podmiotu jako rozwijającego się w czasie. Rzecz jasna, dla Barthes'a takie antropocentryczne

\footnotetext{
78 Tamże, s. 157,159

79 Tamże, s. 119.

80 Tamże, s. 107.

81 Tamże, s. 90.
} 
pojęcia „tożsamości” i „podmiotu” są częścią „porządku wyobrażenia”: podmiot staje się pojmowalny dzięki wyparciu jego językowej konstrukcji. Wracamy tu w zasadzie do naszej początkowej kwestii, do pokrewnej opinii Nietzschego, że nie umiemy znieść „prawdy” o „świecie, który obchodzi coś człowieka” musimy żyć, oszukując samych siebie i wypierając to, co na chwilę zdołaliśmy dostrzec. Możemy też odwołać się znowu do Taylora i zapytać, dlaczego nietzscheańska lub lacanowska charakterystyka człowieka miałyby przezwyciężać język „podmiotu” i „tożsamości” potrzebny Barthes’owi - podobnie jak nam wszystkim - by uchwycić sens swojego życia. Dlaczego podejście czyniące $\mathrm{z}$,języka” ostateczne ramy znaczenia miałoby być prawdziwsze od podejścia wskazującego na intuicyjne rozumienie siebie w czasie, rozumienie, które jak się przekonaliśmy - nie pozwala się z relacji Rolanda Barthes'a o Rolandzie Barcie wykorzenić? Owszem, rozumienie to obejmuje „transcendencję”, stawiając teraźniejszość na uprzywilejowanej pozycji wobec przeszłości, nawet jednak czujny Barthes musi uznać konieczność „powrotu” do takich „wyobrażeń”, równie nieuniknionych jak nasz „powrót” do tego czy innego „łóżka”.

Uznanie tej konieczności jest krokiem naprzód w porównaniu z argumentem ad hominem, którego użyłem w stosunku do Nietzschego. Jak powiedziałem, praktyka pokazuje, że niemiecki filozof nie wciela swojego sceptycyzmu metafizycznego we własne myślenie i odczucia na temat ludzkiego świata, ale nie pokazuje, że Nietzsche nie potrafi tego zrobić. Barthes natomiast wyraźnie zbliża się tu do stwierdzenia, iż nie może się „rozproszyć” w efektach języka, kiedy zaczyna pisać o sobie - nie może się wymknąć z porządku wyobrażenia. Jest to równoznaczne ze stanowiskiem Taylora, który podkreśla, że gdy chcemy uchwycić sens swojego życia, gęste języki antropocentryczne są nam nieodzownie potrzebne. Ujmując rzecz inaczej: rzadkie trzecioosobowe języki teorii postsausurre'owskiej nie są w stanie sprostać wielu celom biografii pierwszoosobowej. Barthes, trzeba zaznaczyć, daje od czasu do czasu poznać, że jest świadomy tych ograniczeń języka teoretycznego. We fragmencie „Szantażowanie teorii” narzeka na teksty awangardowe, których „oczywista wartość związana jest z intencją: mają służyć teorii”. A ponieważ w ten sposób jej służą, domagają się aprobaty ze strony takich ludzi jak Barthes:

kochajcie mnie, strzeżcie, brońcie, bo pasuję do teorii, na którą się powołujecie; czyż nie robię tego samego, co Artaud, Cage i inni? - Tyle że Artaud to nie tylko „awangarda”; to także literatura; Cage ma także wiele uroku... - To właśnie cechy, których teoria nie uznaje, a nawet je wyrzyguje. Uzgodnijcie chociaż swoje upodobania z ideami, i tak dalej ${ }^{82}$.

Jest to uwaga wiele mówiąca, pokazuje bowiem, że mierząc się ze swoim doświadczeniem sztuki, Barthes jest zmuszony sięgać po pojęcia gęstego opisu.

82 Tamże, s. 64-65. 
„Urok” Cage'a nie tylko nie znajduje uznania teorii, ale nawet bywa przez nią „wyrzygiwany”. „Urok” zaś to element języka rozeznawania duchowego, który pozwala Barthes'owi rozróżniać wartości jakościowe - element opisowy i zarazem wartościujący, taki, jakiego trzeba, by wyrażać „upodobania” i krytyczne oceny. Rzadkie języki awangardowych „idei” nie są w stanie rozeznać tych cech w sztuce - ani w doświadczaniu jej przez Barthes’a.

Są to momenty aporetyczne przez to, że sam tekst Barthes'a również jest dziełem jego „idei” raczej niż stosowaniem gęstego opisu do własnego życia. Podobnie jak krytykowane powyżej teksty awangardowe, Roland Barthes jest przede wszystkim konstrukcją teoretycznej intencji. Oznacza to stanowczą decyzję, by nie mówić o sobie autobiograficznie, nie odsłaniać się w narracji konfesyjnej. W pewnym miejscu czytamy: „jam jest Ten, który o nim nie mówi” - co przypomina trochę zalecenie Brechta, by aktorzy myśleli „o roli w trzeciej osobie" 83 . Jak jednak obserwowaliśmy, aporetyczne fragmenty pod kilkoma względami udaremniają tę antyautobiograficzną intencję. Zamiar wpisania „R.B.” wyłącznie w przestrzeń słabych wartościowań „preferencjalizmu” zawodzi tam, gdzie Barthes określa siebie jako kogoś będącego na marginesie, kogoś, kto od zawsze przeciwstawia się „naturalności” i bezmyślnym ortodoksjom społecznym. Jest w tym niewątpliwe poczucie moralne, przejaw podmiotu definiowanego w kategoriach silnego wartościowania. Sprzeciw wobec głuszącej „arogancji” triumfalnych języków ortodoksji, nauki i bojowej polityki odzwierciedla konsekwentne angażowanie się po stronie ekspresywistycznej moralności znaku. W tym sensie „R.B.” jest podmiotem w przestrzeni moralnej. Widać też, że mimo jawnego zamiaru wyrzeczenia się narracyjności Barthes intuicyjnie postrzega swoje życie jako narrację w czasie, jako historię swoich progresów i regresów. Trudno wreszcie nie zauważyć, że Barthes nie potrafi się obejść bez gęstych pojęć wartościujących, takich jak „arogancja” i „urok”, które pozwalają mu rozeznać i wyrazić to, co ma dla niego znaczenie - pojęć definiujących go w nieteoretycznych językach jego konstytutywnych zainteresowań.

$\mathrm{Z}$ przedstawionych tu powodów Roland Barthes pomaga określić pewne konstytutywne cechy myślenia i odczuwania związanego z własnym życiem i samym sobą - cechy nieodzowne w każdej autobiografii godnej tej nazwy. W Autorelacji Wang Shimina elementy te występują bez osłonek, taka bowiem była kultura autora, kształtowana w ogromnej mierze przez konfucjańską etykę i inne czynniki. Późnomodernistyczna czy postmodernistyczna kultura zachodnia jest diametralnie różna. Silnie wartościowane dobra formujące „ja” trzeba wydobywać po stuleciach „wyparcia” - jak mówi Taylor - w procesie bardzo zbliżonym do dekonstrukcji, w którym rozeznaje się konstytutywne cechy pisarstwa autobiograficznego w aporiach teoretycznej intencji. Aporie takie są oznakami nieudanego „doświadczenia” (by wrócić do terminologii Nietzschego), które wskazują, że antyrealizm wartości nie daje się wcielać w codzienne

83 Tamże, s. 182-183. 
życie. Konkretniej: aporie wskazują, że neonietzscheańskie i postsaussure'owskie języki teoretyczne nie są w stanie przejść Taylorowskiego „testu”. Nie można usunąć bogatszych języków wartości potrzebnych autobiografom, by przeżywać swoje życie oraz o nim pisać.

Copyright (C) 2007 by Cornell University, publikacja za zgodą wydawcy, Cornell University Press

Ttumaczenie Anna Skucińska 